\title{
Shifting Baselines to Thresholds: Reframing Exploitation in the Marine Environment
}

\author{
Lane M. Atmore ${ }^{1 *+}$, Magie Aiken ${ }^{2 *}$ and Fabricio Furni ${ }^{3}$ \\ ${ }^{1}$ Department of Biosciences, Centre for Ecological and Evolutionary Synthesis, University of Oslo, Oslo, Norway, ${ }^{2}$ Section \\ for Evolutionary Genomics, Globe Institute, University of Copenhagen, Copenhagen, Denmark, ${ }^{3}$ Marine Evolution \\ and Conservation, Groningen Institute of Evolutionary Sciences, University of Groningen, Groningen, Netherlands
}

OPEN ACCESS

Edited by:

Rowan Trebilco,

Centre for Marine Socioecology,

Australia

Reviewed by:

Francine Kershaw,

Natural Resources Defense Council,

United States

Jess Melbourne-Thomas,

Oceans and Atmosphere (CSIRO),

Australia

*Correspondence:

Lane M. Atmore

lane@palaeome.org

Magie Aiken

magie@palaeome.org

tThese authors have contributed equally to this work and share first

authorship

Specialty section:

This article was submitted to

Marine Conservation

and Sustainability,

a section of the journal

Frontiers in Marine Science

Received: 15 July 2021

Accepted: 15 October 2021

Published: 19 November 2021

Citation:

Atmore LM, Aiken M and Furni F (2021) Shifting Baselines

to Thresholds: Reframing Exploitation

in the Marine Environment.

Front. Mar. Sci. 8:742188.

doi: $10.3389 /$ fmars.2021.742188
Current research on anthropogenic impacts on marine ecosystems often relies on the concept of a "baseline," which aims to describe ecosystems prior to human contact. Recent research is increasingly showing that humans have been involved in marine ecosystems for much longer than previously understood. We propose a theoretical framework oriented around a system of "thresholds" referring to systemwide changes in human culture, ecosystem dynamics, and molecular evolution. The concept of the threshold allows conceptual space to account for the fluid nature of ecosystems throughout time while providing a critical framework for understanding drivers of ecosystem change. We highlight practical research approaches for exploring thresholds in the past and provide key insights for future adaptation to a changing world. To ensure ecological and societal goals for the future are met, it is critical that research efforts are contextualized into a framework that incorporates human society as integral to ecology and evolution.

Keywords: ecology, ancient biomolecules, evolution, conservation, thresholds, sustainability

\section{FROM BASELINES TO THRESHOLDS}

Humans have long been part of marine ecosystems worldwide, although the nature of this relationship has changed over time and space. Today many marine ecosystems are deeply threatened, including commercial fish stocks, coral reefs, and polar environments (Bindoff et al., 2019; Worm and Lotze, 2021). The ongoing crisis in the world's oceans threatens vulnerable species and ecosystems as well as economic stability and food security (FAO, 2018). Further, the world is shifting toward relying even more heavily on the ocean (Costello et al., 2020). From these trends, it is clear that research must address the maintenance of ocean ecosystems. To balance the various needs of all ecosystem actors, both human and non-human, it is crucial that we have language and theory that reflects the dynamic nature of marine ecosystems and our place in them.

Addressing the problem of ocean ecosystem degradation requires enormous interdisciplinary effort. This effort, however, is often stymied by the way in which knowledge creation occurs in marine science. In 1995, Daniel Pauly published a paper on the now-famous phenomenon known as "shifting baselines syndrome (SBS)," in which collective environmental knowledge and memory move forward in time with successive generations, resulting in gradual loss of knowledge regarding the previous state of an ecosystem (Pauly, 1995). Continuous environmental degradation can result in a misinterpretation of changes over time, frequently leading to under-valuation of environmental carrying capacities or species population sizes (Lotze and Worm, 2009; Rodrigues et al., 2019) making researchers ill-equipped to fully understand changing ecosystems. Yet, the environments 
being studied have been transformed by human actions, often for a much longer time period than is commonly assumed (Lotze and Worm, 2009; Rodrigues et al., 2019).

Although the prevalence of SBS has been clearly demonstrated, the concept itself relies on a problematic ecological assumption: that there is a "baseline" for any one species or ecosystem dynamic. This implies a singular, natural state for any particular ecosystem, which, in practice, becomes fraught with arbitrary decisions regarding how a "baseline" is determined (Lotze and Worm, 2009; Rodrigues et al., 2019). To illustrate this point, Collins et al. (2020) estimated historical population sizes of hunted North American mammals throughout history using two different historical time points as cut-offs for baseline calculation. They found that by pushing the timeline back 100 years, population size estimates increased by over $10 \%$, suggesting the original estimates were likely misleading due to the arbitrary designation of a temporal baseline. Such studies are crucial in illustrating the arbitrary nature of baseline determination while acknowledging the equally important role baseline assumptions play in knowledge creation.

It is clear that humans have had a significant and deleterious effect on our surrounding ecosystems in our more recent history. Yet, it is also important to emphasize that humans have played a role in our environments for the entirety of our evolutionary history, including coastal and marine ecosystems (Rick and Erlandson(eds), 2008; Stringer et al., 2008). This role was neither inherently positive nor inherently negative our long relationship with the marine environment and the increasingly appreciated dynamic nature of ecosystem stability illustrates the fact that the "baseline" concept itself is what should be shifting. Rather than focusing on a baseline, the concept of SBS should be incorporated into a wider theoretical framework of thresholds in marine environments which explicitly incorporates human culture as an integral component of marine ecosystems. As will be discussed below, the concept of the threshold allows conceptual space for the fluid nature of ecosystems throughout time. It also provides markers for establishing baselines and a critical framework for understanding drivers of ecosystem change.

By incorporating SBS into a larger discussion of thresholds, the debate can be shifted back to understanding long-term ecosystem dynamics rather than elucidating concrete baselines. Further, the concept of thresholds expands the timescale further than that of SBS, allowing complete incorporation of ecological and evolutionary dynamics into the discussion of sustainable resource management. Finally, as we will show, SBS can be conceptualized as a key component within the wider threshold structure as a cultural characteristic that facilitates the crossing of a certain type of threshold-the tipping point.

We recognize that some of these concepts have been previously addressed in other studies and reviews (Groffman et al., 2006; Samhouri et al., 2010; Rodrigues et al., 2019). Here, we propose a framework that seeks not to disprove other attempts but to expand and enhance inquiry into past ecosystems. We propose a generalized research approach. We emphasize the way in which recent advances in molecular research can illuminate long-term ecosystem change when they are firmly grounded in theory that explicitly incorporates human society in our understanding of what constitutes an "ecosystem." We situate this framework within previous theoretical work, including SBS. We then highlight knowledge gaps in ecological and evolutionary thresholds that can be addressed through biomolecular methods that have become increasingly efficient and accessible in recent years, such as genomics and palaeo/archaeo-genomics and stable isotopes analysis. Finally, we provide suggestions for future research and the impact such studies could have on providing crucial information for future environmental resource management.

\section{DEFINING THRESHOLDS IN MARINE ECOSYSTEMS}

The technical definition of a "threshold" in the Oxford English Dictionary is, "[ $\mathrm{t}]$ he magnitude or intensity that must be exceeded for a certain reaction or phenomenon to occur" (OED, 2021). We use this definition of "threshold" to define various subtypes of threshold that are relevant for understanding marine ecosystems: the magnitude or intensity of some driver increases or decreases to the point that a threshold is crossed. Here we highlight three major threshold categories that pertain to change in marine ecosystems: cultural, ecological, and evolutionary (see Table 1) and discuss various research techniques to identify when a threshold has been crossed, e.g., a certain reaction or phenomenon has occurred. For each category, threshold identification is always dependent on the research question: it relies on the reaction or phenomenon of interest in the study.

When discussing marine resource exploitation, there are several major ways in which a threshold can be identified. The first is to pinpoint times in the past at which human societies experienced a major transition that coincided with changes in relationships to marine ecosystems: thresholds in culture. These thresholds are based on phenomena such as changes in perception of marine environments, technological loss/innovation, economic development, and changes in resource use fall into this category. Thresholds in culture signify a shift in human society that impacts societal-level relationships with the surrounding environment. There are several cultural thresholds that have been identified in human history and are widely known, including the Neolithic and Industrial "revolutions" and the rise of the Information Age. It should be noted, however, that shorter or seemingly less dramatic periods of flux can also be considered cultural thresholds though this is dependent on the scale of the study and the research question. Some examples of cultural thresholds include religious change, technological advance, and political regime changes (including societal collapse). These changes often affect the relationship between humans and their environments, even if indirectly, through changing subsistence patterns, access to novel food sources through trade, and changing economic and political regulations. Cultural thresholds that impact human exploitation in the marine environment are varied and often relate to technological advance (e.g., seafaring technology or improved fishing techniques) (Unger, 1980; Couper, 2009; O'Connor et al., 2011; Montenegro et al., 2016), but can also be linked to cultural mores surrounding 
seafood consumption, as seen with the arrival of Christianity in northern Europe and the associated increase in fish consumption on religious holidays in lieu of meat (Hoffmann, 2001, 2005; Müldner and Richards, 2005). Although these cultural changes can (and often do) have ecological implications, impacting the ecology is not a requirement for a cultural threshold.

The second category of thresholds characterizes ecosystem boundaries according to species biology or ecological traits. These are thresholds in ecology. Thresholds in ecology encompass relationships between species in an ecosystem (e.g., mutualism, predation, symbiotic relationships, trophic balance, etc.) and can refer to radical shifts in ecosystem dynamics as a whole. Again, the threshold is scalable depending on the research aims. Thresholds in ecology can be linked to anthropogenic impacts but may also occur naturally, such as in the process of ecosystem turnover. Thresholds in ecology can also be driven by abiotic factors, both extrinsic, such as the introduction of pollutants or chemicals, and intrinsic, such as biogeological processes like shifting currents and changes in upwelling. Such ecological thresholds are commonly used in exploitation policies today. For example, fisheries policies are often based on measures of spawning-stock biomass-the number of fish in a species that can reproduce in any given year-requiring that human extraction levels do not cause the population to dip below a certain threshold based on the minimum remaining stock size calculated for sustaining the population (De Lara et al., 2007). We here avoid the terms "ecosystem services" and "ecosystem function" as these have been used in the past to create hierarchies between human societies and their surrounding ecosystems and frame management goals purely in terms of how these ecosystems can benefit humans (de Groot, 1987; de Groot et al., 2002; Costanza et al., 2017). We recognize that the definition of the term "ecosystem function" has been under debate in ecological research for some time (Paterson et al., 2012). As it can be used as an underpinning for determining ecosystem services and occasionally synonymously with "ecosystem services" (e.g., Peterson et al., 2010; Oliver et al., 2015; Hillman et al., 2018), we choose to avoid this term altogether.

Finally, there are thresholds in evolution. Evolutionary thresholds are crossed when there is a heritable change in genotype or phenotype in a species. For simplicity's sake, we here discuss molecular evolution as the main example for crossing and evolutionary threshold. This includes demographic shifts such as bottlenecks and population expansions, selective processes and inbreeding, and other phylogenomic phenomena. Potential drivers of threshold crossing include: species migration, climate change, and abiotic factors such as ocean acidification and temperature changes. In recent history, many of these thresholds are likely reached due to human activity, but may have been nonanthropogenic in the past. In this paper, we focus on human exploitation as a critical example of how anthropogenic change can induce an evolutionary threshold. For example, the concept of fisheries-induced evolution postulates that intensive fishing pressures cause an evolutionary change in fish species, mostly by changing life-history traits for faster maturation (Heino et al., 2015; Pinsky et al., 2021). Fisheries-induced evolution occurs when fishing has reached a scale in which evolution is impacted, which may be temporally decoupled from the ecological or cultural thresholds.

Recent discourse in ecosystem management, on anthropogenic impacts on the environment, and on climate change has revolved around the notion of maintaining human activity and ecosystem dynamics within a set of sustainable boundaries often referred to as "thresholds" or "tipping points" (Lenton and Schellnhuber, 2007; Rockström et al., 2009; Russill and Nyssa, 2009). As these terms are not often concretely distinguished, we suggest a differentiation between them. A threshold is distinct from a "tipping point" in that it does not inherently imply a system that has lost crucial regulatory elements. A tipping point can be a form of a threshold, but thresholds exist which are not "tipping points." For example, quantification of sprat population size dynamics has revealed distinct thresholds at which the Baltic Sea ecosystem transitions to an alternate stable state (Casini et al., 2009) but the overall ecosystem dynamics remain unchanged. In contrast, extractivist policies based on research generated under SBS is a cultural characteristic that is causing our oceans to hurtle toward global fisheries collapse and near-total ecosystem degradation (Pauly, 1995; Jackson et al., 2001; Roberts, 2007; Bindoff et al., 2019), therefore is key to crossing the tipping point. Crossing this threshold would be nothing short of catastrophic, which only serves to highlight the importance of deepening our understanding of the other three thresholds. Establishing how thresholds in culture, ecology, and evolution are crossed is therefore of crucial importance to better inform ecosystem management efforts and foster novel approaches to avoid tipping points.

Although seemingly straightforward in definition, these thresholds are in practice entwined in complex, interdependent relationships. For example, advances in fishing technology constitute not only a cultural threshold, but also ecological and evolutionary thresholds as selective fishing and its ecological impact will act as new elements in the marine environment, e.g., with the advent of deep-sea trawling. Given the complexity of human behavior, ecosystem dynamics, and species evolution, it is critical to explore these thresholds thoroughly both in conjunction and as separate phenomena. It can be difficult to determine at what point a threshold has been crossed or what should be considered a "threshold." The threshold concept is not one-size-fits-all, rather it is a flexible approach that can be scaled across time and space.

\section{DETERMINING THRESHOLDS: A GENERALIZED APPROACH}

Here, we lay out the ideal workflow for addressing the issue of identifying thresholds in marine ecosystems in the context of marine resource exploitation. First, context must be grounded in historical, paleontological, archeological, and anthropological research. This includes consultation of historical records, archeological site reports, and, where applicable, ethnographies. Critically, what this means for ecologists is directly searching for answers to ecological/evolutionary questions outside the field 
of ecology. A strong background in the relevant historical and archeological contexts of the time period and/or biological system in question shifts ecological inquiry away from assumptions that long-term change must be caused by abiotic factors, such as climate, whereas only recent changes can be due to human activity in the ecosystem. Concurrently, a relevant background in the natural history of the biological system in question is crucial for framing the historical and archeological context. Biomolecular analysis can then be carried out. This work must be situated in archeology, history, indigenous knowledge, and ecology in order to interpret results in a nuanced approach based in systems-level thinking.

Archeology, anthropology, and historical research are key methodological approaches with which to explore cultural thresholds. The application of these methods, however, are not stand-alone modes of inquiry into the problem of identifying sustainable practices. Research must be framed in the context of archeology, history and, wherever applicable, indigenous knowledge. Incorporating all types of knowledge is the only way we will be able to balance issues such as food security with the pressing problems of declining biodiversity, climate change, and social justice.

Many studies of marine resource extraction set their baseline as the mid- or early twentieth century, citing a drastic change in technology that allowed for increased fishing capacity in hitherto inaccessible regions of the globe (Pinnegar and Engelhard, 2008). This is, of course, an important cultural threshold in marine resource extraction and one that merits attention. It is likely, however, that industrial-scale exploitation was occurring, for at least some populations, much earlier than the twentieth century. In the Atlantic, archeological and historical research has revealed fisheries on an enormous scale occurring up to 1,000 years ago (Barrett, 2019). Indeed, Barrett et al. (2004) propose that a cultural threshold was crossed at this time in the form of the "Fish Event Horizon," in which the English proto-industrial fishing operations reached a high enough level that the surrounding North Sea ecosystems were forever changed. These conclusions were reached based on zooarchaeological analysis in combination with analysis of historical documents, suggesting that the midor early twentieth century baselines established for many marine populations are again subject to SBS. This illustrates the capacity of archeological and historical research to exhibit thresholds in human culture that indicate likely parallel ecological thresholds. While providing significant insights, these sources remain limited for generating a comprehensive understanding of the marine ecosystem. Archeological and historical research efforts are adept at determining thresholds in human behavior such as major societal changes or shifts in scale of exploitation, yet both are less well-equipped for informing us about species or ecosystem dynamics (Barrett, 2019; Oosting et al., 2019).

Molecular analysis of archeological assemblages, undertaken in collaboration with archeologists and historians, can provide novel insight into broader ecological questions. These approaches include stable isotope analysis, proteomics, and genomics, often in conjunction with archeology and paleontology to form the discipline of biomolecular archaeo/paleontology. The research aims that can be addressed include: species identification (Biard et al., 2017); establishing trade, migration, and population continuity (Star et al., 2017); reconstructing demographic history and evolutionary change (De Bruyn et al., 2009; Foote et al., 2013); and analyzing past ecological and climatic conditions (Gokhman et al., 2017). Recent advances in ancient biomolecular techniques have created a novel arena for investigating thresholds, one that is already beginning to take shape in bioarchaeology and marine ecology (Martínez-García et al., 2021; Ólafsdóttir et al., 2021). By reconstructing past ecosystems using ancient DNA and stable isotope analysis, it may be possible to observe periods of stability and flux, providing a better understanding of what constitutes a balanced and sustainable ecosystem in support of future-oriented conservation efforts. Indeed, ecological principles identified through molecular approaches could provide policymakers and scientists with the knowledge necessary to not only recover damaged ecosystems but to help foster novel ecosystems in the coming years (Alagona et al., 2012; Máñez et al., 2014).

We recognize that such an approach to inquiry requires generalized knowledge and a strong collaborative research network that draws on expertise in each of these fields. In recent years, such networks have been established in marine ecology (e.g. Oceans Past Initiative, 2021; Sea Change Project, 2021; SeaChanges Itn, 2021). We anticipate that as the field turns toward incorporating social science and humanities, we will see an influx of networks of this type increasing.

\section{Determining Thresholds: Molecular Methods}

Molecular methods in thresholds analysis often take the form of biomolecular archeology. This typically involves collecting remains from archeological sites, such as bones or other preserved tissue, to extract informative molecules from these samples. Although traditional morphological studies are typically used to understand faunal assemblages from archeological sites, molecular approaches can provide novel insight into broader ecological questions. To illustrate the potential of biomolecular archeology for research on marine thresholds, we highlight the fields of palaeogenomics and stable isotope analysis as well as the emerging field of palaeoproteomics to illustrate the power of biomolecular archeology to provide crucial information for research into marine thresholds.

\section{Palaeogenomics}

The field of palaeogenomics has come into its own in the last decade with the accessibility of ancient DNA laboratories and genomic sequencing techniques (Dabney et al., 2013). This has allowed the field to conduct molecular analysis to a scope that was previously not possible with the prior limited capacity for ancient genome sequencing, opening up new applications for ancient DNA (Rawlence et al., 2021 and references therein). Since then, ancient DNA has been extensively used to explore the relationship between humans and animal species, both wild and domesticated, mainly focused on large terrestrial land mammals and hominids (Meyer, 1992; Dabney et al., 2013; Druzhkova et al., 2013; Woods et al., 2018). However, remains from fish, marine mammals, and other aquatic species are often recovered from 
archeological sites and included in zooarchaeological analyses. This large corpus of predominantly unanalyzed material from marine animals should not be overlooked.

Molecular approaches can bypass many of the limitations of traditional zooarchaeological analysis and provide key insight on issues such as species identification (Biard et al., 2017; Rodrigues et al., 2018), establishing origin (Star et al., 2017), and demographic history (Nye et al., 2020). Similar methodologies have been extensively employed to research domesticates, large prehistoric mammals, and humans (Green et al., 2010; Lorenzen et al., 2011; Meyer et al., 2012; Librado et al., 2017; MacHugh et al., 2017). However, palaeogenomic analysis is far less frequently applied to marine populations, particularly those heavily exploited by humans, both past and present (Oosting et al., 2019). In the last few years, the use of ancient marine samples has begun to increase as laboratory techniques for such samples have improved (Boessenkool et al., 2017; Der Sarkissian et al., 2020; Ferrari et al., 2021b; Martínez-García et al., 2021).

The use of aDNA and reconstructive genomics can provide a deeper time scale than historical catch records. With new bioinformatic techniques, ancient genetic data integrate seamlessly with modern data (Ferrari et al., 2021a; Speidel et al., 2021), for instance allowing temporal assessments of overall population size or population of origin, something that is challenging to achieve using traditional archeological and historical methods (Star et al., 2017; Smith B.T. et al., 2021; van der Valk et al., 2021). By reconstructing past ecosystems using ancient DNA, it may be possible to see changing relationships between human society and the marine ecosystem, thereby providing a better understanding of what constitutes a sustainable ecosystem and key tools for futureoriented conservation efforts. For example, Welch et al. (2012) successfully applied ancient DNA analysis to identify local extirpations in the endemic Hawaiian petrel, illustrating range contraction of the species over time and providing guidance for future conservation efforts. Similar approaches have been used to identify possible source populations for reintroducing Eurasian beavers to the United Kingdom (Marr et al., 2018). By establishing a time series of population dynamics that is hundreds to thousands of years old, it is, for the first time, possible to clarify long-term evolutionary trends for exploited populations and their likely drivers, whether those drivers be anthropogenic or otherwise.

Ancient DNA can also be used to identify cultural patterns, which could help elucidate past cultural thresholds. For example, studies of dental calculus - calcified plaque on tooth remains-is a treasure trove of information on the ancient oral microbiome (Warinner et al., 2015). Analysis of dental calculus in human remains has revealed information on past diets, medicinal use, and ancient dental practices and associated cultural shifts (Blatt et al., 2011; Adler et al., 2013; Warinner et al., 2014; Sawafuji et al., 2020). As of yet no studies specifically link dental calculus to marine exploitation, but that does not preclude its potential applicability to understanding changing marine resources. Ancient genomes can also be used to trace patterns of human migrations and associated changes in land use and subsistence (Racimo et al., 2020). Past patterns of human migration are often linked to cultural and/or biological replacement of pre-existing populations (Li et al., 2014), indicating large cultural thresholds could be crossed during periods of mass migration. Modern genomic sequences are often used to study past migrations to great effect (Leslie et al., 2015). Yet, the addition of ancient DNA can provide time-calibrations and an extended window into the past for some of these migrations that greatly alters our understanding of past cultures (Margaryan et al., 2020). These examples, which document Viking expansion into the islands that include the present-day United Kingdom and Ireland, can be used to assess past cultural relationships with the sea, as Viking culture is well-known to have been dependent in large part on marine subsistence, in contrast to some of the populations they conquered (Naumann et al., 2014).

It is often assumed that humans entering a new environment irrevocably change the ecosystem and, thus, efforts for "rewilding" or restoration rely on the premise that whatever existed prior to human interaction is the "natural" state of the ecosystem. Emerging evidence from palaeogenomic studies shows that, while humans have of course changed marine environments, the narrative that drives the human-ecosystem binary is over-simplifying the true state of ecosystem dynamics. For example, the Grand Banks Atlantic cod population famously collapsed in the 1990s, to the devastation of local communities (Myers et al., 1997). The cod population has still not rebounded, resulting in a trophic cascade around the Newfoundland coast (Frank et al., 2005; Neuenhoff et al., 2019). Yet, recent analysis has shown that, despite the severe population bottleneck the Atlantic cod population has suffered in the last few decades, their genetic diversity remains stable and, thus, old phenotypes and ecosystem dynamics may still be recovered (Pinsky et al., 2021). Studies such as this challenge the long-held assumption that intense exploitation of fisheries must inherently result in evolutionary threshold-crossing on the species-level and emphasize that there are pathways forward for maintaining human-marine relationships that allow both sustainable interaction and exploitation of marine resources and balancing ecosystem dynamics. Similar studies have shown that genetic diversity is robust to periods of intense human exploitation in various species (Welch et al., 2012; Paijmans et al., 2020; Martínez-García et al., 2021).

These studies highlight the importance of not conflating different thresholds. Ecological thresholds were crossed in the Grand Banks as the ecosystem shifted to an alternate stable state, yet genomic results show that molecular evolutionary thresholds have not yet been crossed. Further, they illustrate that while cultural thresholds in exploitation may be informative for identifying ecological and evolutionary thresholds, one must be sure not to project cultural thresholds onto the environment as points of no return. The example of the Grand Banks cod industry also highlights the importance of scale in determining thresholds. At the regional level, the Grand Banks cod population seems to be on the cusp of recovery, as illustrated above. Yet, in some locations an ecological tipping point threshold has, indeed, been passed even if a molecular extinction threshold has not been shown, with local populations in some areas heading quickly toward 
TABLE 1 | The three thresholds.

\begin{tabular}{|c|c|c|c|}
\hline Threshold & Definition & Examples of drivers & Examples of thresholds \\
\hline Cultural & $\begin{array}{l}\text { Major societal transitions that coincide with changes in } \\
\text { relationships to marine ecosystems, often resulting in } \\
\text { changed societal perception and use of nature and/or } \\
\text { marine environments }\end{array}$ & $\begin{array}{l}\text { The invention of trawling; the Industrial } \\
\text { Revolution; Animal domestication } \\
\text { events; Onset of the North American } \\
\text { Fur Trade; The invention of motorized } \\
\text { vessels }\end{array}$ & $\begin{array}{l}\text { Dietary change; Economical shift; Urbanization of } \\
\text { coastal areas }\end{array}$ \\
\hline Ecological & $\begin{array}{l}\text { A boundary in ecosystem dynamics that results in a } \\
\text { balance shift within and/or between ecosystems. This } \\
\text { can occur at the inter- and intra-species level or be } \\
\text { related to abiotic factors }\end{array}$ & $\begin{array}{l}\text { Glacial Periods; Climate Change; } \\
\text { Extirpation events; Population density } \\
\text { of particular species; Onset of pollution }\end{array}$ & $\begin{array}{l}\text { Species richness; trophic interactions; populations } \\
\text { connectivity; distribution of species; historical } \\
\text { population size }\end{array}$ \\
\hline Evolutionary & $\begin{array}{l}\text { A heritable change in a species' genotype or phenotype } \\
\text { that impacts a population larger than a single lineage }\end{array}$ & $\begin{array}{l}\text { Growth/reductions in population size; } \\
\text { Isolation; Changes in sexual selection; } \\
\text { adaptation to environmental changes }\end{array}$ & $\begin{array}{l}\text { The evolution of lactase persistence in humans; } \\
\text { Creation of domesticated animal species/breeds; } \\
\text { adaptive potential; accumulation of deleterious } \\
\text { mutations; diversity gain or loss }\end{array}$ \\
\hline
\end{tabular}

extirpation (Swain et al., 2015, 2019). This illustrates the necessity of identifying thresholds across different geographic and ecological scales and the interplay between thresholds at various levels. There could, for instance, be an evolutionary or ecological threshold that is crossed at the species or regional level when enough local thresholds have been crossed. This is in line with the traditional emphasis in conservation genomics to preserve local populations for species-wide diversity and adaptive potential through techniques like genetic rescue (Supple and Shapiro, 2018).

\section{Stable Isotopes}

Stable isotopes analysis has, much like DNA, been an increasingly accessible tool for archeologists and ecologists alike over the last several decades. Stable isotopes of animal tissue are typically used for analysis of trophic level, dietary reconstruction and foraging ecology, migration, and habitat use. In archeology, stable isotope analysis has been primarily applied to human bone samples. The majority of these studies rely on carbon and nitrogen stable isotope analysis to reconstruct diet, often focused on identifying agricultural transitions (Lee-Thorp, 2008; Sponheimer et al., 2013; Hu, 2018). Other stable isotopic systems including sulfur and oxygen have also been applied to studies of human remains to examine diet (Nehlich et al., 2012; Rand and Nehlich, 2018) and migration (Prowse et al., 2007; Leach et al., 2009; Guo et al., 2018). Applications to past human cultures, particularly those that highlight changing diets and migration, can provide important insights into past cultural thresholds, such as changing religious practices, political regimes, or technological advance that resulted in altered subsistence patterns (Kosiba et al., 2007; Ventresca Miller et al., 2014; Alexander et al., 2019; Cheung et al., 2019). Dietary reconstruction of human populations can identify the incorporation (or lack thereof) of marine resources in the diet (typically requiring a consistent level of consumption over a sustained period) (Goude et al., 2017; McConnan Borstad et al., 2018; Tung and Knudson, 2018). Stable isotopic analysis is increasingly being applied to zooarchaeological remains providing a unique window into the past which can be used to compare to modern ecological studies (Pilaar Birch, 2013). These studies often focus on animal domestication (Hu et al., 2014), seasonality of birth (Frémondeau et al., 2015;
Tornero et al., 2016), and husbandry practices (Cucchi et al., 2016; Manin et al., 2018; Bishop et al., 2020).

In marine systems, stable isotopes have provided proxies for changes in water temperature, salinity, nutrient sources, and food-web complexity (Geffen et al., 2011; Barrett, 2019). Carbon and nitrogen stable isotope analysis have been used to understand foraging ecology (McClellan et al., 2010; Newsome et al., 2010; Szpak et al., 2018, 2019). Due to differences in isotopic discrimination, there are benthic-pelagic differences in $\delta^{13} \mathrm{C}$ values, which results in inshore foragers exhibiting higher $\delta^{13} \mathrm{C}$ values than offshore species (Hobson et al., 1997; Cherel and Hobson, 2007; Andersen et al., 2021). For example, Ólafsdóttir et al. (2021) used zooarchaeological remains associated with Icelandic demersal fisheries to explore the impact of increasing fishing pressure on the trophic levels of Atlantic cod, haddock, and wolffish. By explicitly linking this research to historical and archeological research into the development of the protoindustrial cod fishery in the Medieval era, they were able to compare isotopic signatures over the last 700 years to modern signatures, revealing a strong sign that fishing pressures have both lowered the trophic level for species like cod and resulted in convergence on a single trophic niche for demersal fishes in this environment. Other isotopic systems have also been used, including sulfur as a proxy for foraging ecology (Szpak and Buckley, 2020) and zinc for trophic level in archeological arctic marine mammal bone (Jaouen et al., 2016; McCormack et al., 2021). Oxygen isotopes in marine systems have been used to identify habitat use (Clementz and Koch, 2001; Drago et al., 2020). Guy et al. (2018) used oxygen isotopes to identify fish from a hypersaline lagoon environment in northern Egypt and are able to identify a period of intense exploitation, and trade based on the isotopic signature.

Stable isotope analysis often relies on proxies for data collection. For example, using an innovative approach based on extracting isotopes from ocean quahog, Estrella-Martínez et al. (2019) were able to reconstruct recruitment estimates for the North Sea herring population. Using a marine historical ecology approach, they then cross-checked these estimates with historical resources regarding fishing pressure and catch-per-unit-effort over time. This sort of approach highlights the current ability of molecular research to transform our understanding of the 
interplay between humans and the marine environment. Further, it emphasizes the ability to conduct systems-level analysis (they primarily wanted to investigate primary productivity) from a single isotopic signature when this signature is fully grounded in historical and archeological context.

\section{Palaeoproteomics}

Ancient DNA is an incredibly powerful tool for illuminating past evolutionary dynamics. However, it is dependent on wellpreserved specimens, often restricting research both temporally and geographically (Hofreiter et al., 2014). In contrast to fragile DNA sequences, which begin to degrade immediately post-mortem, proteins are more stable molecules that are less susceptible to degradation over time (Collins et al., 2010). Palaeoproteomics, the extraction of ancient protein molecules from paleontological and archeological remains, is an alternative, minimally destructive method that can also be used on older and less-well-preserved specimens (Welker, 2018). Emerging techniques based on well-established proteomics methods, such as Zooarchaeology by Mass-Spectrometry (ZooMS) can provide taxonomic identification of poorly preserved specimens at relatively low costs without destructive sampling (Buckley et al., 2009; Collins et al., 2010; van Doorn et al., 2011) and provide information for phylogenetic analysis (Welker et al., 2016; Welker, 2018).

Compared to the previously mentioned methods, palaeoproteomic methods are under-developed. Yet, they are still able to shed light on past societal trends of marine resource use, and biological and ecological trends, e.g., shifts in species distributions and changes in resource use (Le Meillour et al., 2020). For example, cetaceans are morphologically hard to identify from traditional zooarchaeological analysis. ZooMS has become an alternative method for more accurate taxonomic identification of these specimens, which might otherwise not be identified (Kitchener et al., 2004; Speller et al., 2016; Rodrigues et al., 2018; van den Hurk et al., 2020, 2021; Wagner et al., 2020). Based on palaeoproteomic data, scientists were able to suggest an expanded distribution range for gray whales in the Mediterranean (Rodrigues et al., 2018), providing information that could be used to define ecological and evolutionary thresholds. When placed in an archeological and historical context, key aspects regarding cultural thresholds have been also explored, such as the dietary use of cetaceans for humans in the Roman and Medieval periods (van den Hurk et al., 2021), and by the American hunter-gatherer-fisher communities of Tierra del Fuego (Evans et al., 2016). Palaeoproteomics can be a stand-alone useful tool for marine areas where preservation of zooarchaeological remains are scarce-e.g., for remains in tropical and subtropical zones (Hofreiter et al., 2014; Speller et al., 2016) - as well as a supportive tool when integrated with other techniques (Evans et al., 2016; Rodrigues et al., 2018).

\section{Determining Thresholds: Practical Limitations}

The ancient biomolecular techniques discussed above are all established avenues of research for better understanding the human and beyond-human past. Yet, each of these techniques is also subject to particular limitations that stem from working with damaged, degraded, and/or partial material. Access to paleontological and archeological materials from which these molecules can be extracted is also a constraint on ancient biomolecular research. As each of these techniques necessitates some form of destructive analysis, research must be carried out painstakingly to minimize the risk of wasteful destruction of unique paleontological and/or archeological materials. Each approach is further limited in scope by the availability of archeological and paleontological remains, which are often biased toward particular regions (terrestrial ecosystems and Europe in particular). There are ongoing efforts to expand these fields into less "traditional" regions of the world (for example, the ERC-funded 4-Oceans project), but this will continue to be limited by both differential preservation in different climates and by problems of access, including funding and training opportunities. Each of these biomolecular techniques additionally has an upper limit on the time depth to which they can be used. Thus far, the oldest ancient DNA ever retrieved was 1 million years old (van der Valk et al., 2021), but the majority of ancient DNA is significantly younger. Both stable isotopes and proteomics can go much further back in time, but are still limited by access to suitable remains for analysis. We here highlight additional limitations that must be considered for each of the proposed biomolecular approaches.

\section{Ancient DNA}

Ancient DNA, while providing a wealth of information, can be costly. Ancient DNA laboratory work requires access to specialized equipment and high-level clean lab protocols to minimize the risk of contamination by modern biomolecules. Ancient DNA has a high risk of contamination, therefore all laboratory work must be conducted by experts in specialized clean facilities for working with old, fragmented DNA. In the past, the sheer cost of conducting ancient DNA lab work (not to mention the associated costs and computational requirements for analysis) has been prohibitive for many labs. However, as high-throughput genomic sequencing has become more prevalent in molecular ecology, population genetics, and medicine, the associated cost of ancient DNA sequencing and analysis has been driven down in conjunction (Der Sarkissian et al., 2015). As a result, the number of ancient genomic sequences being produced has increased exponentially in recent years (Marciniak and Perry, 2017; Skoglund and Mathieson, 2018; Brunson and Reich, 2019). Recent advances in laboratory protocols and bioinformatic techniques have also reduced the impact of bias from post-mortem damage (Jónsson et al., 2013; Schubert et al., 2014; Prüfer, 2018) and expanded the capacity to conduct research on extremely poor-quality data (Ferrari et al., 2021a). The uncertainty associated with analyzing damaged DNA sequences can impact evolutionary analysis, but recent work on methodological development has done much to address this (Prüfer et al., 2010; Martiniano et al., 2020; Orlando et al., 2021). By using ancient DNA in conjunction with modern genomes, some of the limitations of ancient DNA can be addressed and ancient DNA can provide additional insight into deeper evolutionary history than modern genomes alone (for more 
detailed discussion of ancient DNA applications and limitations, see Slatkin and Racimo, 2016; Pont et al., 2019; Spyrou et al., 2019; Dehasque et al., 2020; Smith A. D. et al., 2021).

\section{Stable Isotopes}

Stable isotope analysis of archeological material faces similar problems to the other biomolecular techniques. Sufficiently preserved material must be obtained and destructive analysis is required for collagen extraction (Hoke et al., 2018). The quality of stable isotope results can also be impacted by contamination (Vaiglova et al., 2014) and diagenetic processes that result in isotopic degradation, both of which have been addressed in recently published guidelines for quality-control stable isotope analysis (Guiry and Szpak, 2021). It can also be difficult to determine the comparability of environments across time. For example, whether differences in isotopic signatures across time are merely a reflection of chronology or actually indicate a significant change in environment or diet. This is an issue for $\delta^{15} \mathrm{~N}$ analysis, which is often used in marine ecology and historical ecology to conduct trophic web analysis (Jennings and van der Molen, 2015; Guiry, 2019). In order to account for chronological change, it is often necessary to find $\delta^{15} \mathrm{~N}$ values for a species that would have been close to the baseline of the trophic web both in the past and in the present to provide accurate trophic level estimation for the target species (Post, 2002). It is not always possible to access baseline trophic web species from past ecosystems, thereby limiting the power of trophic web analysis in the past. However, past dietary analysis using carbon and nitrogen signatures is an established and successful field in historical ecology and biomolecular archeology (Miller et al., 2020; Bird et al., 2021), as well as various other applications, including elucidating cultural thresholds in resource use (Lewis and Sealy, 2018; Nord and Billström, 2018; Miller et al., 2020) and geographic region of origin (Hobson, 1999; Lightfoot and O’Connell, 2016).

\section{Palaeoproteomics}

The advantages of palaeoproteomics include being putatively less destructive than stable isotopes and palaeogenomics, and that proteins can be extracted from very old material. However, proteomics and palaeoproteomics cannot provide as fine-scale information as ancient DNA, as it is not yet possible to conduct more than rudimentary evolutionary analysis such as phylogenetic assignment and taxonomic identification (Welker, 2018; Horn et al., 2019). Even if less dependent on material preservation, palaeoproteomics still relies on material quality and protein evolution. Poor recovery of peptides in ancient samples, as well as protein similarities between close-related taxa, can restrict palaeoproteomic studies to identification on higher taxonomic levels (Speller et al., 2016; Buckley, 2018). Existing palaeoproteomics databases also show a strong geographic bias, as research efforts have been concentrated at a small number of institutions in Europe (Welker, 2018). Despite this, recent advances in proteomics show promise for greatly expanding the evolutionary applicability of palaeoproteomics (e.g., Runge et al., 2021) and it will likely be an important field in the near future as more applications are explored.

\section{THRESHOLDS AND RESOURCE MANAGEMENT}

All of the above analytic capacities of ancient biomolecular research are crucial for understanding our past relationship with the marine environment. To establish future sustainable measures for marine resource exploitation, it is necessary to contextualize today's sustainability and conservation efforts with knowledge of the long-term relationships between humans and these ecosystems. The data currently available on human impact are typically collected on decades-long bases, and almost never predates the beginning of the twentieth century. As discussed above, there is strong evidence for industrial-scale marine resource extraction that occurred up to 1,000 years ago, at least in the North Atlantic context and likely elsewhere. This understanding is based on historical records and the analysis of archeological sites and remains. These initial research efforts provide a platform for understanding the human relationship with the sea going far back in time. They also provide context for emerging biomolecular techniques and novel applications. The above methodologies should, therefore, always be conducted with as much ecosystem-wide information as is possible, acknowledging the limitations of working with damaged and/or partial datasets. By exploring the past population dynamics of one species, it is possible to gain long-term information on balanced ecosystem dynamics. This will provide us with tools for avoiding the catastrophic threshold in our near future: the tipping point.

It is too often that thresholds identified for sustainable human exploitation fall under the category of the tipping point, pushing population dynamics to the point of collapse. For example, the commonly used notion of "maximum sustainable yield" in many modern fisheries sets catch limits on exploited species based on the amount of spawning stock biomass that can be sustainably removed from the population (Tsikliras and Froese, 2019). In practice, maximum sustainable yield does not take into account ecosystem dynamics and fluidity, rather it is based mainly on the population size of the focal species, allowing extraction up to the point of population collapse (McEvoy, 1986). In the same way, whaling regulative measures, such as the potential biological removal level defined by the U.S. Marine Mammal Protection act, and the Strike Limit Algorithm by the International Whaling Commission, are also based on the minimum population estimates of the stocks and their carrying capacity (Wade, 1998; Givens, 2000). Application of these and similar approaches have led to marine population collapses around the world due to the combined effects of overexploitation and climate change (Guénette and Gascuel, 2012).

The marine historical ecology approach provides ecosystembased measures for the determination of "sustainable yield" by broadening the definition of the threshold, establishing a conceptual space for ecosystem change that occurs outside of, and prior to, the tipping point. Broadening thresholds allows quantification of population dynamics in focal species that lead to ecosystem perturbation, providing threshold indicators that signal impending population or ecosystem collapse rather 
than driving the system to the breaking point (Duarte et al., 2020). It has been demonstrated that ecosystem complexity and controlled exploitation measures have overwhelmingly positive impacts on human and societal health, the marine environment, and the health of global fisheries (Hutchinson, 2008; Howarth et al., 2014).

By utilizing thresholds that act as boundaries for ecosystem dynamics rather than bringing the population to the tipping point each year, sustainable management measures are more likely to ensure the ecosystem remains stable. Further, FAO nations have pledged since 2003 to put in place ecosystem-based fisheries management (EBFM) practices in fisheries instead of devising policies that only apply to individual species, as was previously the case $(\mathrm{FAO}, 2003)$. In practice, EBFM has been difficult to implement due to the lack of consensus regarding issues of practical application and scale (Trochta et al., 2018), yet is demonstrably crucial to adapting to climate change (Holsman et al., 2020). The threshold concept provides a clear framework for identifying ecosystem, evolutionary, and cultural dynamics that can assist with developing EBFM practices. To effectively enact regulations such as ecosystem-based fisheries management, it is necessary to understand long-term ecosystem dynamics. To do so we must provide space for input from research that emphasizes long timescales and incorporates human society into our understanding of an "ecosystem," a perspective that has long been held by many indigenous communities (Salomon et al., 2014 and references therein).

\section{Case Study-Sea Otters in British Columbia}

We here highlight the example of sea otter conservation management in British Columbia as a case study in how this research approach can be practically applied to policy. Sea otters (Enhydra lustris) are native to the Pacific coasts of North America and northern Asia (Kenyon, 1969). During the North American fur trade of the eighteenth and nineteenth centuries, sea otters were a prized trade item due to their dense, soft fur (Ravalli, 2009; Berg, 2019). By 1929, sea otters were extirpated in British Columbia (BC) (DFO, 2019), and there was near complete extinction of the species (Ravalli, 2009). Sea otters are a critical species for maintaining the kelp forest habitat that used to spread from BC to Baja California (Estes and Palmisano, 1974), a high-productivity environment that likely assisted human migration to the continent $\sim 20,000$ years ago (Erlandson et al., 2007). Sea otters consume invertebrates such as mussels and, most notably, sea urchins; grazing herbivores that can devastate kelp forests when left unchecked (Estes et al., 2016). In the absence of sea otters keeping the invertebrate population low, there have been two main effects. First, the kelp forest habitat along the North American coast has been threatened as a result of the trophic cascade initiated by extirpation of the sea otter (Szpak et al., 2013). Second, a large shellfish industry sprang up in British Columbia, Alaska, and the Pacific coast of the United States to take advantage of the increasing numbers of desirable food species, such as abalones and clams (Gamble, 2021).
In $\mathrm{BC}$, there has been a campaign to reintroduce sea otters to the region in an effort to save kelp forests from devastation by sea urchins. Beginning in the 1960s and 1970s, this campaign has successfully reintroduced sea otters to various places along the coast of BC (DFO, 2019). A 2009 Department of Fisheries and Oceans (DFO) Canada report showed a population increase rate of $19 \%$ per year from 1977 to 1995 , before slowing to a rate of $8.4 \%$ per year from 1995 to 2008, with associated patterns in range expansion (Nichol et al., 2009). With increasing population density and ongoing range expansion, BC sea otters have begun to impact shellfisheries in the region, as shellfish are a shared prey among humans and otters. While otters are not the only factor resulting in diminishing returns from shellfisheries (other factors such as pollution and climate change are crucial components as well), they have become a point of contention among fishers and indigenous communities (Gregr et al., 2020; Gamble, 2021).

Szpak et al. (2012) examined the isotopic signatures of otter remains on Haida Gwaii, an island near Vancouver Island with a long history of occupation (Salomon et al., 2014, 2018). They found that over the course of the last 12,000 years, the $\delta^{15} \mathrm{~N}$ and $\delta^{13} \mathrm{C}$ signatures of sea otters around the island indicated the otters consumed a diet of primarily benthic invertebrates rather than benthic fish. Contextualizing these results with historical and ethnographic work, Szpak et al. (2012) concluded that these isotopic signatures reflect the longterm management strategies indigenous communities practiced to keep the sea otter population low. This conclusion was supported by further research efforts in ethnography, archeology, ecology, and history (Salomon et al., 2014 and references therein; Stevenson et al., 2015) not to mention indigenous activism and participation in sea otter conservation efforts (Salomon et al., 2018).

Slade et al. (2021) further analyzed this pattern by showing that mussel size over the course of occupation on Haida Gwaii was consistent with low levels of predation by sea otters. They go on to argue that current conservation DFO efforts, which are based on estimations of environmental carrying capacity in an abstract world in which humans are not present, are actually increasing otter population density beyond what the environment would have experienced over the last 12,000 years, thereby causing reductions in invertebrate populations that are threatening shellfisheries (Gamble, 2021; Slade et al., 2021). Recent historical ecology work has shown that the coastal ecosystems of $\mathrm{BC}$ were intensively managed by indigenous communities (Salomon et al., 2014), including selective culling of sea otter populations. This ultimately led to a localized system of mosaic micro-environments in which areas near human settlements were comparable to today's sea urchin barrens and areas further away from humans were thick with kelp forests and sea otters, a pattern which is mirrored in research on sea otters and ecosystem stability today (Smith J. G. et al., 2021). While there were likely fluctuations in local environmental stability, the regional environment remained stable over the course of the late Holocene.

Sea otters are an animal of great importance to the indigenous communities of BC (Salomon et al., 2018). Under current DFO 
regulations, indigenous communities are only allowed to take 500 sea otters from the total population (Salomon et al., 2018; Gamble, 2021). First Nations activists have argued recently that in order to provide balance between sea otters and people, and by extension invertebrates and kelp forests, they should be able to practice the traditional management techniques of the past, including increasing the amount of sea otters that can be removed from the ocean each year (Salomon et al., 2018). This is just one critical aspect of first nations' perspectives on resource management in the $\mathrm{BC}$ coastal region (Lee et al., 2019). The recent biomolecular archeology work cited above has strengthened the argument that sea otter management cannot be based purely on false assumptions of "pristine" environments that existed prior to humans.

We highlight this case study not to argue for or against a particular mode of sea otter conservation management, but to illustrate the utility of our research approach. Through the use of ancient biomolecules, archeology, history, and ethnography, research on sea otter management in BC has revealed key thresholds for sea otter management that can be directly applied through policy: thresholds in sea otter population density (ecological) and thresholds in sea otter hunting (cultural). This research has provided new evidence showing localized, mosaic management techniques that persisted over thousands of years, resulting in long-term ecological and cultural stability in the region that endured through the late Holocene. Further research in this area could incorporate more direct applications toward threshold identification, including using ancient DNA to model sea otter population sizes in the past, that could be directly applied to management strategies and inform sea otter conservation.

The authors would like to note that sea otter conservation is a controversial issue. This case study is merely meant to illustrate the applicability of the thresholds research approach. For more information on the issue of sea otter conservation in BC, please see articles published in Hakai magazine (such as Salomon et al., 2014, 2018; Gamble, 2021, and references therein, Gregr et al., 2020; Slade et al., 2021).

\section{CONCLUSION}

To effectively conduct research on changing marine ecosystems, common frameworks and terminology are required. For compelling communication between researchers, this framework must be flexible enough to encompass a myriad of different fields and scales, and requires a shift to incorporate humans and human society into our understanding of the environment. We have introduced a new theoretical language and a generalized approach that incorporates commonly used ecological ideas to address these issues. The thresholds theory is a way to conceptualize ecosystems and ecosystem change that is both flexible and scalable to the research questions being addressed, and lends itself well to practical applications.

We will never return to the oceans of old. It is not the aim of this research to provide pathways for doing so. Rather, it will likely be required to foster new ecosystems as we move forward into the future (Alagona et al., 2012; Duarte et al., 2020), therefore it is crucial to understand what constitutes a balanced ecosystem, the issue of ecosystem complexity, and the role humans might play in these ecosystems. In addition to establishing regulation and oversight to provide future sustainable marine management, consideration must be given to long-term evolution that has occurred between people and marine environments around the globe, such as the interplay between indigenous communities and sea otters in BC during the late Holocene. Funding efforts for marine historical ecology should be directed toward archeology and population genomics analysis for the marine ecosystems on which people most directly depend, including a targeted effort to fund research occurring outside the traditional spheres of Europe and North America. To provide food security in a changing world, the species people depend on need to be understood from an evolutionary standpoint; how have they adapted to past climate change, anthropogenic exploitation, and different actors in their ecosystems? Are balanced ecosystem dynamics in a north Atlantic context the same as in a Pacific island context? What are the local boundaries management programs must navigate to ensure ecosystem balance? Through the thresholds framework, marine historical ecology is poised to answer these questions and provide crucial information for establishing sustainable marine ecosystems for future generations of humans and the species living with them.

\section{DATA AVAILABILITY STATEMENT}

The original contributions presented in the study are included in the article/supplementary material, further inquiries can be directed to the corresponding author/s.

\section{AUTHOR CONTRIBUTIONS}

LA and MA wrote the manuscript with contributions from FF. All authors contributed to the development of the theory and revised, and accepted the manuscript.

\section{FUNDING}

This project has received funding from the European Union's Horizon 2020 Research and Innovation Programme under the Marie Skłodowska-Curie grant agreement no. 813383. The European Research Agency is not responsible for any use that may be made of the information it contains.

\section{ACKNOWLEDGMENTS}

This article was edited by Bastiaan Star, Camilla Speller, and Morten Tange Olsen. A previous version of this article appeared in the Briefing Document for the SeaChanges International Doctoral Training Network presented to the European Commission in September 2020. 


\section{REFERENCES}

Adler, C. J., Dobney, K., Weyrich, L. S., Kaidonis, J., Walker, A. W., Haak, W., et al. (2013). Sequencing ancient calcified dental plaque shows changes in oral microbiota with dietary shifts of the neolithic and industrial revolutions. Nat. Genet. 45, 450455.e1. doi: 10.1038/ng.2536

Alagona, P. S., Sandlos, J., and Wiersma, Y. F. (2012). Past imperfect: using historical ecology and baseline data for conservation and restoration projects in north America. Environ. Philos. 9, 49-70. doi: 10.5840/envirophil2012914

Alexander, M. M., Gutiérrez, A., Millard, A. R., Richards, M. P., and Gerrard, C. M. (2019). Economic and socio-cultural consequences of changing political rule on human and faunal diets in medieval Valencia (c. fifth-fifteenth century AD) as evidenced by stable isotopes. Arch. Anthr. Sci. 11, 3875-3893. doi: 10.1007/s12520-019-00810- $\mathrm{x}$

Andersen, L. W., Jacobsen, M. W., and Szpak, P. (2021). "Chapter 10 - molecular advances in archaeological and biological research on atlantic walrus," in The Atlantic Walrus, eds X. Keighley, M. T. Olsen, P. Jordan, and S. Desjardins (Academic Press), 215-249.

Barrett, J. H. (2019). An environmental (pre)history of european fishing: past and future archaeological contributions to sustainable fisheries. J. Fish Biol. 94, 1033-1044. doi: $10.1111 /$ jb 13929

Barrett, J. H., Locker, A. M., and Roberts, C. M. (2004). Dark age economics' revisited: the english fish bone evidence AD 600-1600. Antiquity 78, 618-636. doi: $10.1017 / \mathrm{s} 0003598 \times 00113262$

Berg, M. (2019). "Sea otters and iron: a global microhistory of value and exchange at nootka sound, 1774-1792.". Past Present 242, 50-82. doi: 10.1093/pastj/gtz038

Biard, V., Gol'din, P., Gladilina, E., Vishnyakova, K., McGrath, K., Vieira, F. G., et al. (2017). Genomic and proteomic identification of late holocene remains: setting baselines for black sea odontocetes. J. Arch. Sci. Rep. 15, 262-271. doi: 10.1016/j.jasrep.2017.07.008

Bindoff, N. L., Cheung, W. W. L., Kairo, J. G., Arístegui, J., Guinder, V. A., Hallberg, R., et al. (2019). "Changing ocean, marine ecosystems, and dependent communities," in IPCC Special Report on the Ocean and Cryosphere in a Changing Climate, eds H. O. Pörtner, D. C. Roberts, V. Masson-Delmotte, P. Zhai, and M. Tignor.

Bird, M. I., Crabtree, S. A., Haig, J., Ulm, S., and Wurster, C. M. (2021). A global carbon and nitrogen isotope perspective on modern and ancient human diet. Proc. Natl. Acad. Sci. 118:e2024642118. doi: 10.1073/pnas.2024642118

Bishop, K. G., Garvie-Lok, S., Haagsma, M., MacKinnon, M., and Karapanou, S. (2020). Mobile animal management in the mediterranean: investigating hellenistic (323-31 BCE) husbandry practices in thessaly, greece using $\delta 13 \mathrm{C}$, $\delta 18 \mathrm{O}$, and $87 \mathrm{Sr} / 86 \mathrm{Sr}$ recorded from sheep and goat tooth enamel. J. Arch. Sci. Rep. 31:102331. doi: 10.1016/j.jasrep.2020.102331

Blatt, S. H., Redmond, B. G., Cassman, V., and Sciulli, P. W. (2011). Dirty teeth and ancient trade: evidence of cotton fibres in human dental calculus from late woodland, ohio. Int. J. Osteoarchaeol. 21, 669-678.

Boessenkool, S., Hanghøj, K., Nistelberger, H. M., Der Sarkissian, C., Gondek, A. T., Orlando, L., et al. (2017). Combining bleach and mild predigestion improves ancient DNA recovery from bones. Mol. Ecol. Res. 17, 742-751. doi: 10.1111/ 1755-0998.12623

Brunson, K., and Reich, D. (2019). The promise of paleogenomics beyond our own species. Trends Genet. 35, 319-329. doi: 10.1016/j.tig.2019.02.006

Buckley, M. (2018). "Paleoproteomics: an introduction to the analysis of ancient proteins by soft ionisation mass spectrometry," in Paleogenomics, eds C. Lindqvist, and O. Rajora (Cham: Springer), 31-52. doi: 10.1007/978-3030-04753-5

Buckley, M., Collins, M., Thomas-Oates, J., and Wilson, J. C. (2009). Species identification by analysis of bone collagen using matrix-assisted laser desorption/ionisation time-of-flight mass spectrometry. Rapid Commun. Mass Spectr. RCM 23, 3843-3854. doi: 10.1002/rcm.4316

Casini, M., Hjelm, J., Molinero, J., Lövgren, J., Cardinale, M., Bartolino, V., et al. (2009). Trophic cascades promote threshold-like shifts in pelagic marine ecosystems. Proc. Natl. Acad. Sci. U.S.A. 106, 197-202. doi: 10.1073/pnas. 0806649105

Cherel, Y., and Hobson, K. A. (2007). Geographical variation in carbon stable isotope signatures of marine predators: a tool to investigate their foraging areas in the southern ocean. Mari. Ecol. Prog. Ser. 329, 281-287. doi: 10.3354/ meps329281
Cheung, C., Zhang, H., Hepburn, J. C., Yang, D. Y., and Richards, M. P. (2019). Stable isotope and dental caries data reveal abrupt changes in subsistence economy in ancient china in response to global climate change. PLoS One 14:e0218943. doi: 10.1371/journal.pone.0218943

Clementz, M. T., and Koch, P. L. (2001). Differentiating aquatic mammal habitat and foraging ecology with stable isotopes in tooth enamel. Oecologia 129, 461-472. doi: 10.1007/s004420100745

Collins, A. C., Böhm, M., and Collen, B. (2020). Choice of baseline affects historical population trends in hunted mammals of north america. Biol. Conserv. 242:108421. doi: 10.1016/j.biocon.2020.108421

Collins, M., Buckley, M., Grundy, H. H., and Thomas-Oates, J. (2010). ZooMS: the collagen barcode and fingerprints. Spectr. Eur. 22, 1-5.

Costanza, R., de Groot, R., Braat, L., Kubiszewski, I., Fioramonti, L., Sutton, P., et al. (2017). "Twenty years of ecosystem services: how far have we come and how far do we still need to go?" Ecosyst. Services 28, 1-16. doi: 10.1016/j.ecoser.2017.09. 008

Costello, C., Cao, L., Gelcich, S., Cisneros-Mata, M. Á, Free, C. M., Froehlich, H. E., et al. (2020). The future of food from the sea. Nature 588, 95-100.

Couper, A. (2009). A Maritime History of the Pacific Peoples. Honolulu, HI: University of Hawai'i Press.

Cucchi, T., Dai, L., Balasse, M., Zhao, C., Gao, J., Hu, Y., et al. (2016). Social complexification and pig (Sus Scrofa) husbandry in ancient china: a combined geometric morphometric and isotopic approach. PLoS One 11:1-20. doi: 10. 1371/journal.pone.0158523

Dabney, J., Knapp, M., Glocke, I., Gansauge, M., Weihmann, A., Nickel, B., et al. (2013). Complete mitochondrial genome sequence of a middle pleistocene cave bear reconstructed from ultrashort DNA fragments. Proc. Natl. Acad. Sci. U.S.A. 110, 15758-15763. doi: 10.1073/pnas.1314445110

De Bruyn, M., Hall, B. L., Chauke, L. F., Baroni, C., Koch, P. L., and Rus Hoelzel, A. (2009). Rapid response of a marine mammal species to holocene climate and habitat change. PLoS Genet. 5:7.

de Groot, R. S. (1987). Environmental functions as a unifying concept for ecology and economics. Environmentalist 7, 105-109. doi: 10.1007/BF0224 0292

de Groot, R. S., Wilson, M. A., and Boumans, R. M. J. (2002). A typology for the classification, description and valuation of ecosystem functions, goods and services. Ecol. Econ. 41, 393-408. doi: 10.1016/S0921-8009(02)00 089-7

De Lara, M., Doyen, L., Guilbaud, T., and Rochet, M. (2007). Is a management framework based on spawning-stock biomass indicators sustainable? A viability approach. ICES J. Mari. Sci. J. Du Conseil 64, 761-767. doi: 10.1093/icesjms/ fsm024

Der Sarkissian, C., Allentoft, M. E., Ávila-Arcos, M. C., Barnett, R., Campos, P. F., Cappellini, E., et al. (2015). Ancient genomics. Philos. Trans. R. Soc. London B Biol. Sci. 370:387. doi: 10.1098/rstb.2013.0387

Dehasque, M., Ávila-Arcos, M. C., íez-del-Molino, D. D., Fumagalli, M., Guschanski, K., Lorenzen, E. D., et al. (2020). Inference of natural selection from ancient DNA. Evol. Lett. 4, 94-108. doi: 10.1002/evl3.165

DFO (2019). Sea Otter Research Program. Available online at: https://www.dfompo.gc.ca/species-especes/mammals-mammiferesseaotterloutremer/indexeng.html (accessed September 26, 2021).

Der Sarkissian, C., Möller, P., Hofman, C. A., Ilsøe, P., Rick, T. C., Schiøtte, T., et al. (2020). Unveiling the ecological applications of ancient DNA from mollusk shells. Front. Ecol. Evol. 8:37.

van Doorn, N. L., Hollund, H., and Collins, M. J. (2011). A novel and non-destructive approach for ZooMS analysis: ammonium bicarbonate buffer extraction. Archaeol. Anthropol. Sci. 3:281. doi: 10.1007/s12520-0110067-y

Drago, M., Valdivia, M., Bragg, D., González, E. M., Aguilar, A., and Cardona, L. (2020). Stable oxygen isotopes reveal habitat use by marine mammals in the río de la plata estuary and adjoining atlantic ocean. Estuar. Coastal Shelf Sci. 238:106708. doi: $10.1016 /$ j.ecss.2020.106708

Druzhkova, A. S., Thalmann, O., Trifonov, V. A., Leonard, J. A., Vorobieva, N. V. Ovodov, N. D., et al. (2013). Ancient DNA analysis affirms the canid from altai as a primitive dog. PLoS One 8:e57754. doi: 10.1371/journal.pone.005 7754

Duarte, C. M., Agusti, S., Barbier, E., Britten, G. L., Carlos Castilla, J., Gattuso, J. et al. (2020). Rebuilding marine life. Nature 580, 39-51. 
Erlandson, J. M., Graham, M. H., Bourque, B. J., Corbett, D., Estes, J. A., and Steneck, R. S. (2007). The kelp highway hypothesis: marine ecology, the coastal migration theory, and the peopling of the Americas. J. Island Coastal Arch. 2, 161-174.

Estes, J. A., and Palmisano, J. F. (1974). Sea otters: their role in structuring nearshore communities. Sciences 185, 1058-1060. doi: 10.1126/science.185. 4156.1058

Estes, J. A., Burdin, A., and Doak, D. F. (2016). Sea otters, kelp forests, and the extinction of the steller's sea cow. Proc. Natl. Acad. Sci. U.S.A. 113, 880-885. doi: 10.1073/pnas.1502552112

Estrella-Martínez, J., Schöne, B. R., Thurstan, R. H., Capuzzo, E., Scourse, J. D., and Butler, P. G. (2019). Reconstruction of Atlantic herring (Clupea harengus) recruitment in the North Sea for the past 455 years based on the $\delta^{13} \mathrm{C}$ from annual shell increments of the ocean quahog (Arctica islandica). Fish Fish. 20, 537-551. doi: 10.1111/faf.12362

Evans, S., Álvarez, M., Rowsell, K., Collier, P., Prosser de Goodall, R. N., Mulville, J., et al. (2016). Using combined biomolecular methods to explore whale exploitation and social aggregation in hunter-gatherer-fisher society in tierra del fuego. J. Arch. Sci. Rep. 6, 757-767.

FAO (2003). The Ecosystem Approach to Fisheries. Italy: FAO.

FAO (2018). The State of Food and Agriculture 2018. Rome: Migration, Agriculture and Rural Development.

Ferrari, G., Cuevas, A., Gondek-Wyrozemska, A. T., Ballantyne, R., Kersten, O., Pálsdóttir, A. H., et al. (2021b). The preservation of ancient DNA in archaeological fish bone. J. Arch. Sci. 126:105317. doi: 10.1073/pnas. 1803573115

Ferrari, G., Atmore, L. M., Jentoft, S., Jakobsen, K. S., Makowiecki, D., Barrett, J. H., et al. (2021a). An accurate assignment test for extremely low-coverage whole-genome sequence data. bioRxiv [preprint]. doi: 10.1101/2021.06.04. 447098

Foote, A. D., Kaschner, K., Schultze, S. E., Garilao, C., Ho, S. Y. W., Post, K., et al. (2013). Ancient DNA reveals that bowhead whale lineages survived late pleistocene climate change and habitat shifts. Nat. Commun. 4:1677. doi: 10 . 1038/ncomms 2714

Frank, K. T., Brian, P., Choi, J. S., and Leggett, W. C. (2005). Trophic cascades in a formerly cod-dominated ecosystem. Science 308, 1621-1623. doi: 10.1126/ science. 1113075

Frémondeau, D., Horard-Herbin, M., Buchsenschutz, O., Ughetto-Monfrin, J., and Balasse, M. (2015). Standardized pork production at the celtic village of levroux les arènes (france, 2nd C. BC): evidence from kill-off patterns and birth seasonality inferred from enamel $\delta 18 \mathrm{O}$ analysis. J. Arch. Sci. Rep. 2, 215-226.

Gamble, J. (2021). The America's First Ecosystem Managers. Hakai Magazine. Available online at: https://www.hakaimagazine.com/news/the-americas-firstecosystem-managers/ (accessed September 25, 2021).

Geffen, A. J., Høie, H., Folkvord, A., Hufthammer, A. K., Andersson, C., Ninnemann, U., et al. (2011). High-latitude climate variability and its effect on fisheries resources as revealed by fossil cod otoliths. ICES J. Mari. Sci. J. Du Conseil 68, 1081-1089. doi: 10.1093/icesjms/fsr017

Givens, G. H. (2000). Strike limit algorithm optimisation: a realistic example. J. Cetacean Res. Manage. 2, 75-83.

Gokhman, D., Malul, A., and Carmel, L. (2017). Inferring past environments from ancient epigenomes. Mol. Biol. Evol. 34, 2429-2438. doi: 10.1093/molbev/ $\operatorname{msx} 211$

Goude, G., Willmes, M., Wood, R., Courtaud, P., Leandri, F., Cesari, J., et al. (2017). New insights into mesolithic human diet in the mediterranean from stable isotope analysis: the sites of campu stefanu and torre d'aquila, corsica. Int. J. Osteoarchaeol. 27, 707-714.

Green, R. E., Krause, J., Briggs, A. W., Maricic, T., Stenzel, U., Kircher, M., et al. (2010). A draft sequence of the neandertal genome. Science 328, 710-722.

Gregr, E., Christensen, V., Nichol, L., Martone, R. G., Markel, R. W., Watson, J. C., et al. (2020). Cascading social-ecological costs and benefits triggered by a recovering keystone predator. Science 368, 1243-1247. doi: 10.1126/science. aay5342

Groffman, P. M., Baron, J. S., Blett, T., Gold, A. J., Goodman, I., Gunderson, L. H., et al. (2006). Ecological thresholds: the key to successful environmental management or an important concept with no practical application? Ecosystems $9,1-13$.
Guénette, S., and Gascuel, D. (2012). Shifting baselines in european fisheries: the case of the celtic sea and bay of biscay. Ocean Coastal Manage. 70, 10-21. doi: 10.1016/j.ocecoaman.2012.06.010

Guiry, E. (2019). Complexities of stable carbon and nitrogen isotope biogeochemistry in ancient freshwater ecosystems: implications for the study of past subsistence and environmental change. Front. Ecol. Evol. 7:313. doi: $10.3389 /$ fevo.2019.00313

Guiry, E., and Szpak, P. (2021). Improved quality control criteria for stable carbon and nitrogen isotope measurements of ancient bone collagen. J. Arch. Sci. 132:104516.

Guo, Y., Fan, Y., Hu, Y., Zhu, J., and Richards, M. P. (2018). Diet transition or human migration in the chinese neolithic? Dietary and migration evidence from the stable isotope analysis of humans and animals from the qinglongquan site, china. Int. J. Osteoarchaeol. 28, 85-94. doi: 10.1002/oa.2465

Guy, S., Thomas, T., Irit, Z., Andreas, P., Dorit, S., Omri, L., et al. (2018). Tooth oxygen isotopes reveal late bronze age origin of mediterranean fish aquaculture and trade. Sci. Rep. 8:14086. doi: 10.1038/s41598-018-32468-1

Heino, M., Díaz Pauli, B., and Dieckmann, U. (2015). Fisheries-induced evolution. Ann. Rev. Ecol. 46, 461-480. doi: 10.1146/annurev-ecolsys-112414054339

Hillman, J. R., Lundquist, C. J., and Thrush, S. F. (2018). The challenges associated with connectivity in ecosystem processes. Front. Mari. Sci. 5:364. doi: 10.3389/ fmars.2018.00364

Hobson, K. A. (1999). "Tracing origins and migration of wildlife using stable isotopes: a review.” Oecologia 120, 314-326. doi: 10.1007/s004420050865

Hobson, K. A., Sease, J. L., Merrick, R. L., and Piatt, J. F. (1997). Investigating trophic relationships of pinnipeds in alaska and washington using stable isotope ratios of nitrogen and carbon. Mari. Mammal Sci. 13, 114-132.

Hoffmann, R. C. (2001). Frontier foods for late medieval consumers: culture, economy, ecology. Environ. History 7, 131-167.

Hoffmann, R. C. (2005). A brief history of aquatic resource use in medieval Europe. Helgoland Mari. Res. 59, 22-30. doi: 10.1007/s10152-004-0203-5

Hofreiter, M., Paijmans, J. L. A., Goodchild, H., Speller, C. F., Barlow, A., Fortes, G. G., et al. (2014). The future of ancient DNA: technical advances and conceptual shifts. BioEssays News Rev. Mol. Cell. Dev. Biol. 37, 284-293. doi: 10.1002/bies.201400160

Holsman, K. K., Haynie, A. C., Hollowed, A. B., Reum, J. C. P., Aydin, K., Hermann, A. J., et al. (2020). Ecosystem-based fisheries management forestalls climate-driven collapse. Nat. Commun. 11:4579. doi: 10.1038/s41467-020-18 300-3

Hoke, N., Rott, A., Johler, S., Reul, A., Beck, A., Günther, A., et al. (2018). How bone degradation, age, and collagen extraction methods affect stable isotope analysis. Arch. Anthr. Sci. 11, 3357-3374.

Horn, I. R., Kenens, Y., Palmblad, N. M., van der Plas-Duivesteijn, S. J., Langeveld, B. W., Meijer, H. J. M., et al. (2019). Palaeoproteomics of bird bones for taxonomic classification. Zool. J. Linnean Soc. 186, 650-665. doi: 10.1093/ zoolinnean/zlz012

Howarth, L. M., Roberts, C. M., Thurstan, R. H., and Stewart, B. D. (2014). The unintended consequences of simplifying the sea: making the case for complexity. Fish Fish. 15, 690-711. doi: 10.1111/faf.12041

van den Hurk, Y., Rielly, K., and Buckley, M. (2021). Cetacean exploitation in roman and medieval london: reconstructing whaling activities by applying zooarchaeological, historical, and biomolecular analysis. J. Arch. Sci. Rep. 36:102795.

van den Hurk, Y., Spindler, L., McGrath, K., and Speller, C. (2020). Medieval Whalers in the Netherlands and flanders: zooarchaeological analysis of medieval cetacean remains. Environ. Arch. 1-15. doi: 10.1080/14614103.2020. 1829296 [Epub ahead of print].

Hutchinson, W. F. (2008). The dangers of ignoring stock complexity in fishery management: the case of the north sea cod. Biol. Lett. 4, 693-695. doi: 10.1098/ rsbl.2008.0443

$\mathrm{Hu}, \mathrm{Y}$. (2018). Thirty-four years of stable isotopic analyses of ancient skeletons in china: an overview, progress and prospects. Archaeometry 60, 144-156. doi: 10.1111/arcm.12367

Hu, Y., Hu, S., Wang, W., Wu, X., Marshall, F. B., Chen, X., et al. (2014). Earliest evidence for commensal processes of cat domestication. Proc. Natl. Acad. Sci. U.S.A. 111, 116-120. doi: 10.1073/pnas.1311439110 
Jackson, J. B., Kirby, M. X., Berger, W. H., Bjorndal, K. A., Botsford, L. W., Bourque, B. J., et al. (2001). Historical overfishing and the recent collapse of coastal ecosystems. Science 293, 629-637. doi: 10.1126/science.105 9199

Jaouen, K., Szpak, P., and Richards, M. P. (2016). Zinc isotope ratios as indicators of diet and trophic level in arctic marine mammals. PLoS One 11:e152299. doi: 10.1371/journal.pone.0152299

Jennings, S., and van der Molen, J. (2015). "Trophic levels of marine consumers from nitrogen stable isotope analysis: estimation and uncertainty.". ICES J. Mari. Sci. 72, 2289-2300. doi: 10.1111/1365-2656.12504

Jónsson, H., Ginolhac, A., Schubert, M., Johnson, P. L., and Orlando, L. (2013). mapDamage2. 0: fast approximate Bayesian estimates of ancient DNA damage parameters. Bioinformatics 29, 1682-1684. doi: 10.1093/bioinformatics/btt193

Kenyon, K. W. (1969). The Sea Otter in the Eastern Pacific Ocean. Washington, D.C: Government Printing Office.

Kitchener, A. C., Bonsall, C., and Bartosiewicz, L. (2004). "Missing mammals from mesolithic middens: a comparison of the fossil and archaeological records from scotland," in Mesolithic Scotland and Its Neighbours the Early Holocene Prehistory of Scotland, its British and Irish Context, and some Northern European Perspectives, ed. A. Saville (Edinburgh: Society of Antiquaries of Scotland), 73-82.

Kosiba, S. B., Tykot, R. H., and Carlsson, D. (2007). Stable isotopes as indicators of change in the food procurement and food preference of viking age and early christian populations on gotland (sweden). J. Anthr. Arch. 26, 394-411. doi: 10.1016/j.jaa.2007.02.001

Le Meillour, L., Zirah, S., Zazzo, A., Cersoy, S., Détroit, F., Imalwa, E., et al. (2020). Palaeoproteomics gives new insight into early southern African pastoralism. Nat. Sci. Rep. 10:14427. doi: 10.1038/s41598-020-71374-3

Leach, S., Lewis, M., Chenery, C., Müldner, G., and Eckardt, H. (2009). Migration and diversity in roman britain: a multidisciplinary approach to the identification of immigrants in roman york, England. Am. J. Phys. Anthr. 140, 546-561. doi: 10.1002/ajpa.21104

Lee, L. C., Reid, M., Jones, R., Winbourne, J., Rutherford, M., and Salomon, A. K. (2019). Drawing on indigenous governance and stewardship to build resilient coastal fisheries: people and abalone along Canada's northwest coast. Mari. Policy 109:103701. doi: 10.1016/j.marpol.2019.103701

Lee-Thorp, J. A. (2008). On isotopes and old bones. Archaeometry 50, 925-950.

Lenton, T. M., and Schellnhuber, H. J. (2007). Tipping the scales. Nat. Clim. Change 1, 97-98.

Leslie, S., Winney, B., Hellenthal, G., Davison, D., Boumertit, A., Day, T., et al. (2015). The fine-scale genetic structure of the british population. Nature 519, 309-314.

Lewis, M. C., and Sealy, J. C. (2018). Coastal complexity ancient human diets inferred from bayesian stable isotope mixing models and a primate analogue. PLoS One 13:e0209411. doi: 10.1371/journal.pone.0209411

Li, S., Schlebusch, C., and Jakobsson, M. (2014). Genetic variation reveals largescale population expansion and migration during the expansion of bantuspeaking peoples. Proc. R. Soc. B Biol. Sci. 281:1793. doi: 10.1098/rspb.2014 1448

Librado, P., Gamba, C., Gaunitz, C., Der Sarkissian, C., Pruvost, M., Albrechtsen, A., et al. (2017). Ancient genomic changes associated with domestication of the horse. Science 356, 442-445. doi: 10.1126/science.aam 5298

Lightfoot, E., and O'Connell, T. C. (2016). On the use of biomineral oxygen isotope data to identify human migrants in the archaeological record: intrasample variation, statistical methods and geographical considerations. PLoS One 11:e0153850. doi: 10.1371/journal.pone.0153850

Lorenzen, E., Nogués-Bravo, D., Orlando, L., Weinstock, J., Binladen, J., Marske, K. A., et al. (2011). Species-specific responses of late quaternary megafauna to climate and humans. Nature 479, 359-364. doi: 10.1038/nature10574

Lotze, H. K., and Worm, B. (2009). Historical baselines for large marine animals. Trends Ecol. Evol. 24, 254-262.

MacHugh, D. E., Larson, G., and Orlando, L. (2017). Taming the past: ancient DNA and the study of animal domestication. Ann. Rev. Animal Biosci. 5, 329-351. doi: 10.1146/annurev-animal-022516-022747

Máñez, K. S., Holm, P., Blight, L., Coll, M., MacDiarmid, A., Ojaveer, H., et al. (2014). The future of the oceans past: towards a global marine historical research initiative. PLoS One 9:e101466. doi: 10.1371/journal.pone.0101466
Manin, A., Corona, E., Alexander, M., Craig, A., Thornton, E. K., Yang, D. Y., et al. (2018). Diversity of management strategies in mesoamerican turkeys: archaeological, isotopic and genetic evidence. R. Soc. Open Sci. 5:171613. doi: 10.1098/rsos.171613

Marciniak, S., and Perry, G. H. (2017). Harnessing ancient genomes to study the history of human adaptation. Nat. Rev. Genet. 18, 659-674. doi: 10.1038/nrg. 2017.65

Margaryan, A., Lawson, D. J., Sikora, M., Racimo, F., Rasmussen, S., Moltke, I., et al. (2020). Population genomics of the viking world. Nature 585, 390-396.

Marr, M. M., Brace, S., Schreve, D. C., and Barnes, I. (2018). Identifying source populations for the reintroduction of the eurasian beaver, Castor Fiber L. 1758, into britain: evidence from ancient DNA. Sci. Rep. 8:2708. doi: 10.1038/s41598018-21173-8

Martínez-García, L., Ferrari, G., Oosting, T., Ballantyne, R., van der Jagt, I., Ystgaard, I., et al. (2021). Historical demographic processes dominate genetic variation in ancient atlantic cod mitogenomes. Front. Ecol. Evol. 9:671281. doi: $10.3389 /$ fevo.2021.671281

Martiniano, R., Garrison, E., Jones, E. R., Manica, A., and Durbin, R. (2020). Removing reference bias and improving indel calling in ancient DNA data analysis by mapping to a sequence variation graph. Genome Biol. 21:250. doi: 10.1186/s13059-020-02160-7

McClellan, C. M., Braun-McNeill, J., Avens, L., Wallace, B. P., and Read, A. J. (2010). Stable isotopes confirm a foraging dichotomy in juvenile loggerhead sea turtles. J. Exp. Mari. Biol. Ecol. 387, 44-51.

McConnan Borstad, C., Garvie-Lok, S., and Katsonopoulou, D. (2018). Diet at ancient helike, achaea, greece based on stable isotope analysis: from the hellenistic to the roman and byzantine periods. J. Arch. Sci. Rep. 18, 1-10.

McCormack, J., Szpak, P., Bourgon, N., Richards, M., Hyland, C., Méjean, P., et al. (2021). Zinc isotopes from archaeological bones provide reliable tropic level information for marine mammals. Commun. Biol. 4:683. doi: 10.1038/s42003021-02212-z

McEvoy, A. F. (1986). The Fisherman's Problem: Ecology and Law in the California Fisheries. Cambridge: Cambridge University Press, 1850-1980.

Meyer, H. (1992). 10,000 years 'high on the hog': some remarks on the humananimal relationship. Anthrozoös 5, 144-159. doi: 10.2752/089279392787011412

Meyer, M., Kircher, M., Gansauge, M., Li, H., Racimo, F., Mallick, S., et al. (2012). A high-coverage genome sequence from an archaic denisovan individual. Science $338,222-226$.

Miller, M. J., Whelton, H. L., Swift, J. A., Maline, S., Hamman, S., Cramp, L. J. E., et al. (2020). Interpreting ancient food practices: stable isotope and molecular analyses of visible and absorbed residues from a year-long cooking experiment. Sci. Rep. 10:13704. doi: 10.1038/s41598-020-70109-8

Montenegro, Á, Callaghan, R. T., and Fitzpatrick, S. M. (2016). Using seafaring simulations and shortest-hop trajectories to model the prehistoric colonization of remote oceania. Proc. Natl. Acad. Sci. U.S.A. 113, 12685-12690. doi: 10.1073/ pnas. 1612426113

Müldner, G., and Richards, M. (2005). Fast or feast: reconstructing diet in later medieval england by stable isotope analysis. J. Arch. Sci. 2, 39-48.

Myers, R. A., Hutchings, J. A., and Barrowman, N. J. (1997). Why do fish stocks collapse? The example of cod in atlantic canada. Ecol. Appl. Publi. Ecol. Soc. Am. 7, 91-106. doi: 10.1890/1051-0761(1997)007[0091:wdfsct]2.0.co;2

Naumann, E., Krzewińska, M., Götherström, A., and Eriksson, G. (2014). Slaves as burial gifts in viking age norway? Evidence from stable isotope and ancient DNA analyses. J. Arch. Sci. 41, 533-540.

Nehlich, O., Fuller, B. T., árquez-Grant, N. M., and Richards, M. P. (2012). Investigation of diachronic dietary patterns on the islands of ibiza and formentera, spain: evidence from sulfur stable isotope ratio analysis. Am. J. Phys. Anthr. 149, 115-124. doi: 10.1002/ajpa.22104

Neuenhoff, R. D., Swain, D. P., Cox, S. P., McAllister, M. K., Trites, A. W., Walters, C. J., et al. (2019). Continued decline of a collapsed population of atlantic cod (gadus morhua) due to predation-driven allee effects. Can. J. Fish. Aquatic Sci. J. Can. Des Sci. Halieutiques et Aquat. 76, 168-184. doi: 10.1139/cjfas-2017-0190

Newsome, S. D., Clementz, M. T., and Koch, P. L. (2010). Using stable isotope biogeochemistry to study marine mammal ecology. Mari. Mammal Sci. 26, 509-572. doi: 10.1111/j.1748-7692.2009.00354.x

Nichol, L. M., Boogaards, M. D., and Abernethy, R. (2009). Recent trends in the abundance and distribution of sea otters in British Columbia. Fish. Oceans Can. Res. Document 1-10. 
Nord, A. G., and Billström, K. (2018). Isotopes in cultural heritage; present and future possibilites. Heritage Sci. 6:25.

Nye, J. W., Zangrando, A. F. J., Paz Martinoli, M., and Fogel, M. L. (2020). Temporal and population trends in human exploited pinnipeds from tierra del fuego. Palaeogeogr. Palaeoclimatol. Palaeoecol. 554:109804. doi: 10.1016/ j.palaeo.2020.109804

Oceans Past Initiative (2021). Available online at: https://oceanspast.org/.(accessed July 6, 2021).

O'Connor, S., Ono, R., and Clarkson, C. (2011). Pelagic fishing at 42,000 years before the present and the maritime skills of modern humans. Science 334, 1117-1121. doi: 10.1126/science.1207703

Ólafsdóttir, G. Á, Edvardsson, R., Timsic, S., and Harrison, R. (2021). A millennium of trophic stability in atlantic cod (gadus morhua): transition to a lower and converging trophic niche in modern times. Sci. Rep. 11:12681. doi: 10.1038/ s41598-021-92243-7

Oliver, T. H., Heard, M. S., Isaac, N. J. B., Roy, D. B., Procter, D., Eigenbrod, F., et al. (2015). Biodiversity and resilience of ecosystem functions. Trends Ecol. Evol. 30, 673-684. doi: 10.1016/j.tree.2015.08.009

Oosting, T., Star, B., Barrett, J. H., Wellenreuther, M., Ritchie, P. A., and Rawlence, N. J. (2019). Unlocking the potential of ancient fish DNA in the genomic era. Evol. Appl. 12, 1513-1522. doi: 10.1111/eva.12811

Orlando, L., Allaby, R., Skoglund, P., Sarkissian, C. Der, Stockhammer, P. W., ÁvilaArcos, M. C., et al. (2021). Ancient DNA analysis. Nat. Rev. Methods Primers $1: 14$.

Paijmans, A. J., Stoffel, M. A., Bester, M. N., Cleary, A. C., Nico De Bruyn, P. J., Forcada, J., et al. (2020). The genetic legacy of extreme exploitation in a polar vertebrate. Sci. Rep. 10:5089.

Paterson, D. M., Defew, E. C., and Jabour, J. (2012). "Ecosystem function and co-evolution of terminology in marine science and management," in Marine Biodiversity and Ecosystem Functioning: Frameworks, methodologies, and integration, eds M. Solan, R. J. Aspden, and D. M. Paterson (Oxford: Oxford University Press), 24-33. doi: 10.1093/acprof:oso/9780199642250.003.0003

Pauly, D. (1995). Anecdotes and the shifting baseline syndrome of fisheries. Trends Ecol. Evol. 10:430. doi: 10.1016/s0169-5347(00)89171-5

Peterson, M. J., Hall, D. M., Feldpausch-Parker, A. M., and Rai Peterson, T. (2010). Obscuring ecosystem function with application of the ecosystem services concept. Conserv. Biol. 24, 113-119. doi: 10.1111/j.1523-1739.2009.01305.x

Pilaar Birch, S. E. (2013). Stable isotopes in zooarchaeology: an introduction. Archaeol. Anthropol. Sci. 5, 81-83. doi: 10.1016/j.dib.2020.10 5974

Pinnegar, J. K., and Engelhard, G. H. (2008). The 'shifting baseline' phenomenon: a global perspective. Rev. Fish Biol. Fish. 18, 1-16. doi: 10.1007/s11948-0099147-0

Pinsky, M. L., Eikeset, A. M., Helmerson, C. I, Bradbury, R., Bentzen, P., Morris, C., et al. (2021). Genomic stability through time despite decades of exploitation in cod on both sides of the atlantic. Proc. Natl. Acad. Sci. U.S.A. 118:15. doi: 10.1073/pnas.2025453118

Pont, C., Wagner, S., Kremer, A., Orlando, L., Plomion, C., and Salse, J. (2019). Paleogenomics: reconstruction of plant evolutionary trajectories from modern and ancient DNA. Genome Biol. 20:29. doi: 10.1186/s13059-019-1627-1

Post, D. (2002). Using stable isotopes to estimate trophic position: models, methods, and assumptions. Ecology 83, 703-718. doi: 10.1111/j.1095-8649. 2012.03251.x

Prowse, T. L., Schwarcz, H. P., Garnsey, P., Knyf, M., Macchiarelli, R., and Bondioli, L. (2007). Isotopic evidence for age-related immigration to imperial rome. Am. J. Phys. Anthr. 132, 510-519. doi: 10.1002/ajpa.20541

Prüfer, K. (2018). snpAD: an ancient DNA genotype caller. Bioinformatics 34, 4165-4171. doi: 10.1093/bioinformatics/bty507

Prüfer, K., Stenzel, U., Hofreiter, M., Pääbo, S., Kelso, J., and Green, R. E. (2010). Computational challenges in the analysis of ancient DNA. Genome Biol. 11:R47.

Racimo, F., Woodbridge, J., Fyfe, R. M., Sikora, M., Sjögren, K., Kristiansen, K., et al. (2020). The spatiotemporal spread of human migrations during the european holocene. Proc. Natl. Acad. Sci. U.S.A. 117, 8989-9000. doi: 10.1073/ pnas. 1920051117

Rand, A. J., and Nehlich, O. (2018). Diet and Sulfur Isotopes.” The Encyclopedia of Archaeological Sciences. Hoboken, NJ: John Wiley \& Sons, Inc., 1-4. doi: $10.1002 / 9781119188230$.saseas 0186

Ravalli, R. (2009). "The near extinction and reemergence of the pacific sea otter, 1850-1938.". Pacific Northwest Quart. 100, 181-191.
Rawlence, N. J., Knapp, M., Martin, M. D., and Wales, N. (2021). Editorial: applied uses of ancient DNA. Front. Ecol. Evol. 9:217.

Rick, T. C., and Erlandson, J. M. (eds) (2008). Archaeology, Historical Ecology, and the Future of Ocean Ecosystems. Impacts on Ancient Marine Ecosystems: A Global Perspective. Berkeley, CA: University of California Press.

Roberts, C. (2007). The Unnatural History of the Sea. Washington, DC: Island Press.

Rockström, J., Steffen, W., Noone, K., Persson, Å, Chapin, F. S., Lambin, E., et al. (2009). Planetary boundaries: exploring the safe operating space for humanity. Ecol. Soc. 14:32.

Rodrigues, A. S. L., Charpentier, A., Bernal-Casasola, D., Gardeisen, A., Nores, C., Pis Millán, J. A., et al. (2018). Forgotten mediterranean calving grounds of grey and north atlantic right whales: evidence from roman archaeological records. Proc. R. Soc. B Biol. Sci. 285:1882. doi: 10.1098/rspb.2018. 0961

Rodrigues, A. S. L., Monsarrat, S., Charpentier, A., Brooks, T. M., Hoffmann, M., Reeves, R., et al. (2019). Unshifting the baseline: a framework for documenting historical population changes and assessing long-term anthropogenic impacts. Philos. Trans. R. Soc. London. Ser. B Biol. Sci. 374:1788. doi: 10.1098/rstb.2019. 0220

Runge, A. K. W., Hendy, J., Richter, K. K., Masson-MacLean, E., and Britton, K. (2021). Palaeoproteomics analyses of dog palaeofaeces reveal a preserved dietary and host digestive proteome. Proc. R. Soc. B Biol. Sci. 288:1954. doi: $10.1098 / \mathrm{rspb} .2021 .0020$

Russill, C., and Nyssa, Z. (2009). The tipping point trend in climate change communication. Global Environ. Change Hum. Policy Dimens. 19, 336-344. doi: 10.1016/j.gloenvcha.2009.04.001

Salomon, A. K., Wilson, K. B. J., Elroy White, X., Tanape, N., and Happynook, T. M. (2014). "First nations perspectives on sea otter conservation in british columbia and alaska: insights into coupled human-ocean systems," in Sea Otter Conservation, ed. L. B. VanBlaricom (Academic Press Elsevie), doi: 10.1016/ B978-0-12-801402-8.00011-1

Salomon, A. K., Burt, J. M., Herb, I., Wilson, K. B., Happynook, H. Y. T., Davidson, S. H. A., et al. (2018). Coastal Voices. Available online at: www.coastalvoices.net (accessed September 26, 2021).

Samhouri, J. F., Levin, P. S., and Ainsworth, C. H. (2010). Identifying thresholds for ecosystem-based management. PLoS One 5:e8907. doi: 10.1371/journal.pone. 0008907

Sawafuji, R., Saso, A., Suda, W., Hattori, M., and Ueda, S. (2020). Ancient DNA analysis of food remains in human dental calculus from the edo period, japan. PLoS One 15:e0226654. doi: 10.1371/journal.pone.0226654

Sea Change Project (2021). Available online at: https://www.seachangeproject. eu/.(accessed July 6,2021$)$

SeaChanges Itn (2021). Available online at: https://sites.google.com/york.ac.uk/ seachanges/home?authuser $=0$. (accessed July 6, 2021).

Schubert, M., Ermini, L., Der Sarkissian, C., Jónsson, H., Ginolhac, A., Schaefer, R., et al. (2014). Characterization of ancient and modern genomes by SNP detection and phylogenomic and metagenomic analysis using PALEOMIX. Nat. Protocols 9, 1056-1082. doi: 10.1038/nprot.2014.063

Skoglund, P., and Mathieson, I. (2018). Ancient genomics of modern humans: the first decade. Ann. Rev. Geno. Hum. Genet. 19, 381-404.

Slade, E., McKechnie, I., and Salomon, A. K. (2021). Archaeological and contemporary evidence indicates low sea otter prevalence on the pacific northwest coast during the late holocene. Ecosystems. 1-19. doi: 10.1007/ s10021-021-00671-3

Slatkin, M., and Racimo, F. (2016). Ancient DNA and human history. Proc. Natl. Acad. Sci. U.S.A. 113, 6380-6387.

Smith, A. D., Kaminski, M. J., Kanda, K., Sweet, A. D., Betancourt, J. L., Holmgren, C. A., et al. (2021). Recovery and analysis of ancient beetle DNA from subfossil packrat middens using high-throughput sequencing. Sci. Rep. 11:12635. doi: 10.1038/s41598-021-91896-8

Smith, B. T., Gehara, M., and Harvey, M. G. (2021). The demography of extinction in eastern north american birds. Proc. R. Soc. B Biol. Sci. 288:20201945.

Smith, J. G., Tomoleoni, J., Staedler, M., Lyon, S., Fujii, J., and Tinker, M. T. (2021). Behavioral responses across a mosaic of ecosystem states restructure a sea otter-urchin trophic cascade. Proc. Natl. Acad. Sci. 118:e2012493118. doi: 10.1073/pnas.2012493118

Speidel, L., Cassidy, L., Davies, R. W., Hellenthal, G., Skoglund, P., and Myers, S. R. (2021). Inferring population histories for ancient genomes using genome-wide genealogies. bioRxiv[preprint]. doi: 10.1101/2021.02.17.431573 
Speller, C., van den Hurk, Y., Charpentier, A., Rodrigues, A., Wilkens, B., McGrath, $\mathrm{K}$., et al. (2016). Barcoding the largest animals on earth: ongoing challenges and molecular solutions in the taxonomic identification of ancient cetaceans. Philos. Trans. R. Soc. London Ser. B Biol. Sci. 371:1702. doi: 10.1098/rstb.2015.0332

Sponheimer, M., Alemseged, Z., Cerling, T. E., Grine, F. E., Kimbel, W. H., Leakey, M. G., et al. (2013). Isotopic evidence of early hominin diets. Proc. Natl. Acad. Sci. U.S.A. 110, 10513-10518. doi: 10.1073/pnas. 1222579110

Spyrou, M. A., Bos, K. I., Herbig, A., and Krause, J. (2019). Ancient pathogen genomics as an emerging tool for infectious disease research. Nat. Rev. Genet. $20,323-340$.

Star, B., Boessenkool, S., Gondek, A. T., Nikulina, E. A., Hufthammer, A. K., Pampoulie, C., et al. (2017). Ancient DNA reveals the arctic origin of viking age cod from haithabu, germany. Proc. Natl. Acad. Sci. U.S.A. 114, 9152-9157. doi: $10.1073 /$ pnas.1710186114

Stevenson, C. F., Demes, K. W., and Salomon, A. K. (2015). Accounting for sizespecific predation improves our ability to predict the strength of a trophic cascade. Ecol. Evol. 6, 1041-1053. doi: 10.1002/ece3.1870

Stringer, C. B., Finlayson, J. C., Barton, R. N. E., Fernandez-Jalvo, Y., Caceres, I., Sabin, R. C., et al. (2008). Neanderthal exploitation of marine mammals in gibraltar. Proc. Natl. Acad. Sci. U.S.A. 105, 14319-14324.

Supple, M. A., and Shapiro, B. (2018). Conservation of biodiversity in the genomics era. Genome Biol. 19:131.

Swain, R., Rolland, N., and Aubry, E. (2019). Assessment of the Southern Gulf of St. Lawrence Atlantic Cod (Gadus Morhua) Stock of NAFO Div. 4T and 4Vn (November to April), March 2019. Available online at: https://waves-vagues.dfompo.gc.ca/Library/40805542.pdf (accessed June 24, 2021).

Swain, D. P., Savoie, L., Cox, S. P., and Aubry, É (2015). Assessment of the Southern Gulf of St. Lawrence Atlantic Cod (Gadus Morhua). Available online at: https: //waves-vagues.dfo-mpo.gc.ca/Library/362226.pdf (accessed June 24, 2021).

Szpak, P., Orchard, T. J., McKechnie, I., and Gröcke, D. R. (2012). Historical ecology of late holocene sea otters (enhydra lutris) from northern British columbia: isotopic and zooarchaeological perspectives. J. Arch. Sci. 39, 15531571.

Szpak, P., Buckley, M., Darwent, C. M., and Richards, M. P. (2018). Longterm ecological changes in marine mammals driven by recent warming in northwestern alaska. Global Change Biol. 24, 490-503. doi: 10.1111/gcb.13880

Szpak, P., Orchard, T. J., Salomon, A. K., and Gröcke, D. R. (2013). Regional ecological variability and impact of the maritime fur trade on nearshore ecosystems in southern Haida Gwaii (British Columbia, Canada): evidence from stable isotope analysis of rockfish (Sebastes spp.) bone collagen. Archaeol. Anthropol. Sci. 5, 159-182. doi: 10.1007/s12520-013-0122-y

Szpak, P., Julien, M., Royle, T. C. A., Savelle, J. M., Yang, D. Y., and Richards, M. P. (2019). Sexual differences in the foraging ecology of 19th century beluga whales (Delphinapterus leucas) from the canadian high arctic. Mari. Mammal Sci. 36, 451-471. doi: 10.1111/mms. 12655

Szpak, P., and Buckley, M. (2020). Sulfur isotopes (834S) in arctic marine mammals: indicators of benthic vs. pelagic foraging. Mari. Ecol. Prog. Ser. 653, 205-216.

OED (2021). threshold, n." OED. Oxford University Press. Available online at: www.oed.com/view/Entry/201234 (accessed September 22, 2021).

Tornero, C., Balasse, M., Molist, M., and Saña, M. (2016). Seasonal reproductive patterns of early domestic sheep at tell halula (PPNB, middle euphrates valley): evidence from sequential oxygen isotope analyses of tooth enamel. J. Arch. Sci. Rep. 6, 810-818. doi: 10.1016/j.jasrep.2015.10.038

Trochta, J. T., Pons, M., Rudd, M. B., Krigbaum, M., Tanz, A., and Hilborn, R. (2018). Ecosystem-based fisheries management: perception on definitions, implementations, and aspirations. PLoS One 13:e0190467. doi: 10.1371/journal. pone. 0190467

Tsikliras, A. C., and Froese, R. (2019). "Maximal sustainable yield," in Encyclopedia of Ecology, ed. D. Brian (Elsevier), 108-115.

Tung, T. A., and Knudson, K. J. (2018). Stable isotope analysis of a pre-hispanic andean community: reconstructing pre-wari and wari era diets in the hinterland of the wari empire, peru. Am. J. Phys. Anthropol. 165, 149-172. doi: 10.1002/ ajpa.23339
Unger, R. W. (1980). Dutch herring, technology, and international trade in the seventeenth century. J. Econ. History 40, 253-280. doi: 10.1017/ s0022050700108204

Vaiglova, P., Snoeck, C., Nitsch, E., Bogaard, A., and Lee-Thorp, J. (2014). Impact of contamination and pre-treatment on stable carbon and nitrogen isotopic composition of charred plant remains. Rapid Commun. Mass Spectr. 28, 24972510. doi: $10.1002 / \mathrm{rcm} .7044$

van der Valk, T., Pečnerová, P., íez-Del-Molino, D. D., Bergström, A., Oppenheimer, J., Hartmann, S., et al. (2021). Million-year-old DNA sheds light on the genomic history of mammoths. Nature 591, 265-269. doi: 10.1038/ s41586-021-03224-9

Ventresca Miller, A., Usmanova, E., Logvin, V., Kalieva, S., Shevnina, I., Logvin, A., et al. (2014). Subsistence and social change in central eurasia: stable isotope analysis of populations spanning the bronze age transition. J. Arch. Sci. 42, 525-538. doi: 10.1016/j.jas.2013.11.012

Wade, P. R. (1998). Calculating limits to the allowable human-caused mortality of cetaceans and pinnipeds. Mari. Mammal Sci. 14, 1-37. doi: 10.1111/j.17487692.1998.tb00688.x

Wagner, A., Richter, K. K., Ludes, E., Arbogast, R., Carita, D., Guidez, A., et al. (2020). Whale bone puzzles: reconstructing and identifying historical whale skeletons using archive records, osteology, and zooarchaeology by mass spectrometry (ZooMS). J. Conserv. Museum Stud. 18, 1-12. doi: 10.5334/jcms. 196

Warinner, C., Matias Rodrigues, J. F., Vyas, R., Trachsel, C., Shved, N., Grossmann, J., et al. (2014). Pathogens and host immunity in the ancient human oral cavity. Nat. Genet. 46, 336-344.

Warinner, C., Speller, C., and Collins, M. J. (2015). A new era in palaeomicrobiology: prospects for ancient dental calculus as a long-term record of the human oral microbiome. Philos. Trans. R. Soc. London Ser. B Biol. Sci. 370:1660. doi: 10.1098/rstb.2013.0376

Welch, A. J., Wiley, A. E., James, H. F., Ostrom, P. H., Stafford, T. W. Jr., and Fleischer, R. C. (2012). Ancient DNA reveals genetic stability despite demographic decline: 3,000 years of population history in the endemic hawaiian petrel. Mol. Biol. Evol. 29, 3729-3740. doi: 10.1093/molbev/mss 185

Welker, F. (2018). Palaeoproteomics for human evolution studies. Quat. Sci. Rev. 190, 137-147. doi: 10.1016/j.quascirev.2018.04.033

Welker, F., Hajdinjak, M., Talamo, S., Jaouen, K., Dannemann, M., David, F., et al. (2016). Palaeoproteomic evidence identifies archaic hominins associated with the châtelperronian at the grotte du renne. Proc. Natl. Acad. Sci. U.S.A. 113, 11162-11167. doi: 10.1073/pnas. 1605834113

Woods, R., Turvey, S. T., Brace, S., MacPhee, R. D. E., and Barnes, I. (2018). Ancient DNA of the extinct jamaican monkey xenothrix reveals extreme insular change within a morphologically conservative radiation. Proc. Natl. Acad. Sci. U.S.A. 115, 12769-12774. doi: 10.1073/pnas.1808603115

Worm, B., and Lotze, H. K. (2021). "Chapter 21 - marine biodiversity and climate change," in Climate Change, ed. T. M. Letcher (Elsevier), 445-464. doi: 10.1016/ b978-0-12-821575-3.00021-9

Conflict of Interest: The authors declare that the research was conducted in the absence of any commercial or financial relationships that could be construed as a potential conflict of interest.

Publisher's Note: All claims expressed in this article are solely those of the authors and do not necessarily represent those of their affiliated organizations, or those of the publisher, the editors and the reviewers. Any product that may be evaluated in this article, or claim that may be made by its manufacturer, is not guaranteed or endorsed by the publisher.

Copyright $(2021$ Atmore, Aiken and Furni. This is an open-access article distributed under the terms of the Creative Commons Attribution License (CC BY). The use, distribution or reproduction in other forums is permitted, provided the original author(s) and the copyright owner(s) are credited and that the original publication in this journal is cited, in accordance with accepted academic practice. No use, distribution or reproduction is permitted which does not comply with these terms. 